УДК 636.27(477).034.082.2

\title{
БІЛОГОЛОВА УКРАЇНСЬКА ПОРОДА ЗА ЧИСТОПОРОДНОГО РОЗВЕДЕННЯ ТА СХРЕЩУВАННЯ
}

\author{
Войтенко Світлана Леонідівна \\ доктор сільськогосподарських наук, профресор \\ Інститут розведення і генетики тварин імені М.В. Зубця НААН \\ ORCID: 0000-0003-3530-6360 \\ Email: slvoitenko@ukr.net
}

\author{
Сидоренко Олена Василівна \\ кандидат сільськогосподарських наук, старший науковий співробітник \\ Інститут розведення і генетики тварин імені М.В. Зубця НАAН \\ ORCID: 0000-0003-2429-9361 \\ Email:sydorenkoolena@ukr.net
}

\begin{abstract}
Методи чистопородного розведення з породою сільськогосподарських тварин дозволяють зберігати породні особливості, закріпляти бажані ознаки родоначальників у потомстві, консолідувати селекційні групи, поліпшувати продуктивність, але на певному етапі роботи з нею виникає проблема інбридингу та зниження рівня продуктивності, які дуже складно вирішити методами внутрішньопородної селекції. Білоголова українська порода великої рогатої худоби наразі відноситься до вітчизняних локальних популяцій, в якій присутні інбредні тварини та яка з огляду на низькі економічно важливі ознаки не може конкурувати не лише з світовими, але й кращими вітчизняними породами. 3 урахуванням чого пошук способів підвищення господарськи корисних ознак тварин та зниження гомозиготності популяції відноситься до актуальних проблем сьогодення. Дослідження проведені на поголів"ї худобі білоголової української породи в ТОВ «Подільський господар» Хмельницької області. Вивчали вплив бугая та року народження на поліпшення господарськи корисних ознак корів за чистопородного розведення, а також можливість використання ввідного схрещування для зниження рівня інбридингу в стаді та підвищення генетичного потенціалу худоби за основними ознаками добору. Для визначення ефективності залучення корів білоголової української породи до виробниитва молока на промисловій основі вивчали результативність їх схрещування з джерсейською породою. Основні селекиійні ознаки визначали за матеріалами бази даних системи управління молочним скотарством (СУМС «Інтесел-Орсек») станом на 1 січня 2018 року. Встановлено, що різниия між найвищою та найнижчою величиною надою корів білоголової української породи за першу лактацію 2009-2014

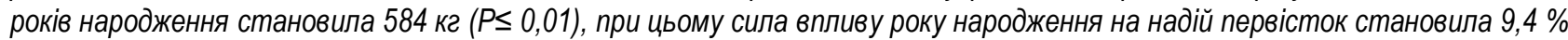
( $p \leq 0,001)$, вміст жиру - 18,0 \% ( $\leq \leq 0,001)$, кількість молочного жиру - 9,4\%. З'ясовано, що найвищою молочною продуктивністю за 3 лактації характеризувалися дочки бугаїв Орла UA235 і Сома UA6800085660, але в иілому вплив плідника на продуктивність корів неістотний, оскільки внутрігрупова різниия надою між високопродуктивними та низькопродуктивними дочірніми потомками одного бугая за кожну з трьох лактацій перевищує міжгрупову. Сила впливу бугая на надій первісток становила 3,4\%. Доведено, що використання ввідного та промислового схрещування підвищує молочну продуктивність у помісних корів, порівняно до чистопородних і можуть бути застосовані як методи підвищення генетичного потенціалу худоби при виробництві молока на племінній та промисловій основі.
\end{abstract}

Ключові слова: худоба, бугаї, рік народження, ввідне та промислове схрещування, чистопородні та помісні тварини, продуктивність.

DOI: https://doi.org/10.32845/bsnau.Ivst.2021.1.8

Загальновідомо, що при виведенні будь-якої породи сільськогосподарських тварин чи ї̈ структурних одиниць використовують відтворне, ввідне, поглинальне схрещування чи гібридизацію. У подальшому, залежно від мети племінної роботи з породою, застосовують чистопородне розведення чи ввідне схрещування. У товарних стадах, для підвищення продуктивності тварин використовують промислове схрещування чи гібридизацію.

Білоголова українська порода, яка наразі відноситься до локальних нечисленних порід, в своєму історичному розвитку теж зазнала неодноразового схрещування, хоча цей метод не завжди спряв поліпшенню ії господарськи корисних ознак. Порода створювалася шляхом схрещування місцевої худоби, здебільшого поліської природнокліматичної зони, з представниками гронінгенського відріддя голландської породи та подальшим добором за молочністю $[4,14]$. у свій час вона була материнською основою при виведенні української чорно-рябої молочної породи, для чого корів білоголової української породи схрещували 3 плідниками голштинської породи. Проте саме цей захід привів практично до знищення породи, яка за 1974-1995 роки скоротилася майже в 30 разів [8]. Для підвищення продуктивності худоби білоголової української породи в окремі роки використовували ввідне схрещування з голландською породою, в результаті чого плідники лінії Марта 171 мають відповідну частку кровності за породою батька, а також з українською чорно-рябою молочною породою, інформація про яких була присутня в родоводах частини корів племінного стада ТОВ «Подільський господар» Хмельницької області [4].

В останні роки при розведенні білоголової української породи застосовують здебільшого чистопородне розведення, але проблемою $є$ інбридинг. Нашими попередніми дослідженнями встановлена можливість застосування в популяції інбридингу різних ступенів, особливо для підвищення інтенсивності росту та відтворної здатності тварин. I хоча аутбредні корови дещо перевищували інбредних за молочною продуктивністю без статистично достовірної 
різниці між ними, споріднене спаровування батьківських пар визнано методом розведення худоби локальної породи, оскільки воно не супроводжується інбредною депресією [6].

З'ясовано, що застосовані методи чистопородного розведення худоби білоголової української породи впродовж 2002-2019 років сприяли підвищенню надою корів з 3033 до 4704 кг (на 1671 кг), а молочного жиру - з 110 до 174 кг (на 64 кг) [25], проте навіть такі темпи удосконалення породи не дозволяють їй конкурувати з кращими вітчизняними породами й бути високорентабельною.

Для виявлення генетичних чинників, які забезпечують підвищення молочної продуктивності за чистопородного розведення, нами у попередні роки був визначений вплив походження за батьком та належності до лінії. Встановлено, що серед корів 4 наявних ліній найвищим надоєм за першу лактацію характеризувалися дочірні потомки ліній Рєзвого 33 та Жаргуна 157. Найвищу молочну продуктивність за першу лактацію своїм дочкам забезпечували бугаї Принц UA445 і Чардаш UA55, які належали до лінії Рєзвого 33. Водночас серед представників цієї лінії виявлені бугаї, яких 3 огляду на молочну продуктивність первісток не бажано використовувати в стаді [5]. Одержані результати слугували основою для подальших досліджень з виявлення кращих плідників і поєднань, які б спряли удосконаленню породи методами внутрішньопородної селекції та забезпечували збереження генетичної мінливості популяції.

Практикою розведення великої рогатої худоби молочного напряму продуктивності з'ясовано, що чистопородне розведення до певного моменту роботи з породою забезпечує підвищення генетичного потенціалу тварин, але у подальшому потрібно застосовувати схрещування. Прикладом вдалого використання схрещування $€$ породи чи помісі, створені на основі голштинської породи. При цьому в країнах походження голштинської породи - США та Канаді, порода удосконалювалася лише методами чистопородного розведення [2], для чого розроблена єдина національна програма селекції з худобою, в основі якої добір за обмеженою кількістю ознак, максимальне використання високоцінних бугаїв, щорічне вибракування 25-30\% корів зі стада, раціональна система вирощування, годівлі й утримання тварин, продуктивне довголіття корів [22].

Варто зазначити, що голштинська порода присутня в родоводах племінної худоби майже всіх порід, які виведені та розводяться в Україні й продовжує використовуватися при поглинальному та міжпородному схрещуванні з метою значного підвищення молочної продуктивності $[1,7,10,15$, 18, 19, 24, 27].

Аналогічна практика схрещування порід для одержання ефекту гетерозису та істотного підвищення окремих кількісних ознак у гібридів першого покоління впроваджена в багатьох провідних країнах світу. Як вказує низка авторів $[12,23]$, гібридні тварини, одержані за схрещування голштинської породи із фрінською айрширською, шведською червоною, данською червоною, джересейською, швіцькою, монбельярд та іншими характеризувалися вищою продуктивністю, кращою якістю молока та продуктивним довголіттям, порівняно з голштинами.

Безперечно, ефективність міжпородного схрещування завдячує не лише ефекту гетерозису, але й ряду інших чинників - годівлі, утриманню, вирощуванні тощо, тому бажання мати високопродуктивних тварин повинно узгоджеватися з сучасним рівнем годівлі та прогресивною технологією виробництва молока.

Виходячи із вищевикладеного, вважаємо актуальними дослідження щодо схрещування корів білоголової української породи з бугаями інших порід, а також визначення окремих генотипових та паратипових чинників, які за чистопородного розведення сприятимуть підвищенню генетичного потенціалу молочної продуктивності худоби.

Мета - підвищення генетичного потенціалу худоби локальної білоголової української породи методами чистопородного розведення та схрещування.

Матеріали та методи досліджень. Дослідження проведені на поголів'ї худоби білоголової української породи в ТОВ «Подільський господар» Хмельницької області. Визначали вплив бугая та року народження корів на їх молочну продуктивність, а також відтворювальну здатність та молочну продуктивність залежно від методу розведення. Для визначення впливу року народження та походження за батьком корови були розділені на 6 різних груп. В першому досліді вивчали продуктивність корів, народжених у 20092014 роках. У другому досліді вивчали молочну продуктивність корів дочок окремих плідників, а саме: бугаїв Злака UA673, Нікеля UA6800410641, Орла UA235, Плюса UA629, Сома UA6800085660 і Цоколя UA6800410646. У третьому досліді вивчали ефективності ввідного схрещування, для чого сформували 2 групи корів, у першу 3 яких увійшли чистопородні тварини білоголової української породи (ч/п БУ), а в другу - помісі першого покоління від схрещування корів білоголової української породи з бугаями гронінгенської породи (50\% БУ + 50\% ГР). В четвертому досліді визначали можливість підвищення молочної продуктивності корів за простого промислового схрещування, для чого сформували 2 групи корів у першу з яких увійшли чистопородні тварини білоголової української породи (ч/п БУ), а в другу помісні тварини першого покоління від схрещування корів білоголової української породи з бугаями джерсейської породи (50\% БУ +50\% Д).

Надій корів за 305 днів лактації, вміст та кількість молочного жиру в молоці, а також вік та живу масу першого плідного осіменіння визначали за матеріалами бази даних системи управління молочним скотарством (СУМС «ІнтеселОрсек») станом на 1 січня 2018 року. Статистичне опрацювання матеріалів досліджень зроблено за використання програмного пакету «STATISTICA 10.0» на ПК. Розмах варіювання (R) молочної продуктивності визначали за різницею між максимальним та мінімальним значенням ознаки. Силу впливу року народження корів та походження за батьком на рівень їх молочної продуктивності вивчали методом однофакторного дисперсійного аналізу через співвідношення факторіальної дисперсії до загальної [16].

Результати досліджень. Встановлено, що корови первістки білоголової української породи заводського стада ТОВ «Подільський господар» Хмельницької області, народжені у 2009-2014 роках, характеризувалися мінливістю за молочною продуктивністю. Так, надій первісток змінювався у залежності від року народження від 4369 кг (2009 рік) до 3887 кг (2014 рік) і найвищого значення мав у 2013 році 4408 кг, відповідно (табл. 1). 
Таблиця 1

Молочна продуктивність корів-первісток залежно від року народження

\begin{tabular}{|c|c|c|c|c|}
\hline \multirow{2}{*}{ Рік народження корови } & \multirow{2}{*}{$\mathrm{|}$} & \multicolumn{3}{|c|}{ Молочна продуктивність } \\
\cline { 3 - 5 } & & надій, кг & жир, \% & $157,3 \pm 6,06$ \\
\hline 2009 & 16 & $4369 \pm 150,44$ & $3,59 \pm 0,04$ & $157,3 \pm 6,19$ \\
\hline 2010 & 24 & $4323 \pm 161,02$ & $3,63 \pm 0,014$ & $139,3 \pm 4,41^{*}$ \\
\hline 2011 & 46 & $3824 \pm 117,71^{\star \star}$ & $3,64 \pm 0,011$ & $159,0 \pm 4,51$ \\
\hline 2012 & 52 & $4343 \pm 116,15$ & $3,65 \pm 0,009$ & $157,5 \pm 2,85$ \\
\hline 2013 & 91 & $4408 \pm 76,78$ & $3,56 \pm 0,08$ & $137,8 \pm 4,64$ \\
\hline
\end{tabular}

Примітка. ${ }^{*}-p \leq 0,05 ;{ }^{* *}-p \leq 0,01$ (порівняно до найбільшого значення ознаки).

Тобто, можна зробити припущення, що найкращими, 3 огляду на надій, для прояву генетичного потенціалу молочної продуктивності корів заводського стада були 2009, 2010, 2012 і 2013 роки. Безперечно, фактор року народження, як один із середовищних чинників, сам по собі не впливає на вирощування корів та їх майбутню продуктивність, адже загальновідомо, що розвиток кількісних ознак залежить від умов годівлі, які були створені тваринам під час вирощування. Тому можна допустити, що вищезазначені роки були сприятливими за кліматичними умовами, забезпечили тваринництво необхідною кормовою базою та збалансованим раціоном годівлі молодняку, ніж у 2011 і 2014 роках, що побічно проявилося у реалізації їх майбутньої молочної продуктивності. Різниця між найвищим та найнижчим надоєм корів становила 584 кг $(\mathrm{P} \leq 0,01)$, що досить суттєво для неконкурентоспроможної локальної породи. Вміст жиру в молоці в динаміці досліджуваних років варіював у межах 3,54-3,65 \% і не залежав від надою корів та року їх народження. Найбільш жирномолочним було молоко корів 2011 та 2012 років народження й містило малу кількість жиру - у 2013 та 2014 роках. Кількість молочного жиру залежала від його надою та жирномолочності й найвищою була у корів 2012 року народження.

За результатами наших досліджень виявлено вплив року народження на ознаки молочної продуктивності корівпервісток білоголової української породи, який за надоєм становив 9,4 \% ( $p \leq 0,001)$, вмістом жиру - 18,0 \% ( $\leq \leq$ 0,001) і кількістю молочного жиру - 9,4\%. Серед наукової спільноти немає єдиної точки зору щодо впливу року народження на молочну продуктивність корів [21, 31, 32], але ми вважаємо, що даний середовищний чинник заслуговує на увагу та урахування при удосконаленні білоголової української породи за основними селекційними ознаками.

Дослідженнями багатьох вчених [3, 9, 13, 17, 20, 26, 30] доведено, що у молочному скотарстві генетичний потенціал стад і порід завдячує передачі спадковості від бугаївплідників, тому варто акцентувати увагу на цьому важливому селекційному чиннику, особливо при чистопородному розведенні худоби локальною, закритою популяцією.

Одержані нами дані щодо продуктивності дочок бугаїв білоголової української породи в ТОВ «Подільський господар» засвідчують значну різницю не лише серед потомків різних бугаїв, але й одного. За даними досліджень, за першу лактацію кращими за надоєм були дочки бугаїв Орла UA 235 і Злака UA673, від яких одержано 4256 і 4223 кг молока і які переважали потомків інших досліджуваних бугаїв на 33-421 кг і 107-388 кг, відповідно, без статистично достовірної різниці (табл. 2).

Таблиця 2

Молочна продуктивність дочок окремих бугаїв-плідників

\begin{tabular}{|c|c|c|c|c|}
\hline Кличка та інд. № бугая & Надій за лактацію, кг & R надою, кг & Жир, \% & Молочний жир, кг \\
\hline \multicolumn{5}{|c|}{ I лактація } \\
\hline 3лак UA673 (n=29) & $4223 \pm 161,35$ & 3341 & $3,56 \pm 0,014$ & $150,5 \pm 5,91$ \\
\hline Нікель UA6800410641 (n=44) & $3835 \pm 131,83$ & 3308 & $3,47 \pm 0,082$ & $132,7 \pm 5,67$ \\
\hline Орел UA235 (n=16) & $4256 \pm 244,82$ & 3814 & $3,62 \pm 0,021$ & $154,9 \pm 9,44$ \\
\hline Плюс UA629 (n=21) & $3894 \pm 216,53$ & 3801 & $3,62 \pm 0,018$ & $141,1 \pm 7,99$ \\
\hline Com UA6800085660 (n=65) & $4116 \pm 93,7$ & 3596 & $3,62 \pm 0,013$ & $148,9 \pm 3,56$ \\
\hline Цоколь UA6800410646 (n=7) & $4086 \pm 147,11$ & 1097 & $3,56 \pm 0,035$ & $145,1 \pm 4,56$ \\
\hline \multicolumn{5}{|c|}{ II лактація } \\
\hline Нікель UA 6800410641 (n=10) & $3945 \pm 345,44$ & 3164 & $3,53 \pm 0,019$ & $139,8 \pm 12,78$ \\
\hline Орел UA 235 (n=16) & $4268 \pm 260,67$ & 4120 & $3,60 \pm 0,039$ & $154,6 \pm 10,32$ \\
\hline Плюс UA 629 (n=21) & $3900 \pm 242,53$ & 3680 & $3,63 \pm 0,021$ & $141,8 \pm 9,14$ \\
\hline Com UA6800085660 $(n=56)$ & $4287 \pm 105,35$ & 3841 & $3,65 \pm 0,008$ & $156,5 \pm 3,86$ \\
\hline \multicolumn{5}{|c|}{ III лактація } \\
\hline Орел UA 629 (n=15) & $4645 \pm 291,71$ & 3655 & $3,64 \pm 0,017$ & $169,4 \pm 11,12$ \\
\hline Плюс UA 629 (n=13) & $4782 \pm 340,22$ & 4350 & $3,61 \pm 0,017$ & $172,8 \pm 12,17$ \\
\hline Com UA6800085660 (n=54) & $4444 \pm 149,42$ & 6264 & $3,56 \pm 0,035$ & $145,1 \pm 4,56$ \\
\hline
\end{tabular}

Низьким надоєм молока за першу лактацію характеризувалися дочки плідників Нікеля UA6800410641 і Плюса UA629, відповідно - 3835 і 3894 кг. Варто також наголосити на істотній мінливості ознаки серед корів одного походження за батьком, підтвердженням чого слугує різниця між показниками кращих та гірших дочок, яка за першою лактацією становила 1097-3814 кг. Тобто, можна допустити, що на прояв генетич- ного потенціалу тварин, окрім бугая, впливають і інші генотипові та середовищні чинники, можливо навіть рік народження, який у наших дослідженнях достовірно підтверджений. Вміст жиру в молоці, з огляду на антагоністичний характер цих ознак, не залежав від надою і змінювався від 3,47\% у дочок бугая Нікеля UA6800410641 до 3,62\% у дочок бугаїв Орла UA625, Плюса UA629 і Сома UA6800085660. Разом з тим 
найвищою кількістю молочного жиру в молоці за першу лактацію характеризувалися дочки бугаїв Орла UA235 і Злака UA673, які мали найвищий надій в стаді.

Кращими за надоєм другої лактації виявились дочки бугая Сома UA6800085660, які перевищували одностадниць з різницею 13-387 кг без статистично достовірної різниці. Корови даного походження характеризувалися найвищим вмістом жиру та виходом молочного жиру (3,65 \% і 156,5 кг, відповідно), але не мали статистично достовірної різниці порівняно до дочок інших бугаїв. Низьким надоєм молока за другу лактацію, як і за першу, відрізнялися дочки плідників Нікеля UA6800410641 і Плюса UA629, відповідно - 3945 3900 кг. Різниця між надоєм високопродуктивних та низькопродуктивних корів спільного походження за батьком за другою лактацією, як і за першою, була теж досить значною (3164-4120 кг), що не може обумовлюватися лише спадковістю бугая.

3'ясовано, що три закінчені лактації в стаді мали лише дочки бугаїв Орла UA 235, Плюса UA629 і Сома UA6800085660. Серед них найкращим було дочірнє потомство бугая Плюса UA629, яке переважало дочок решти досліджуваних плідників за надоєм на 137-338 кг та кількістю молочного жиру на 3,4-27,7 кг. Встановлено, що і за третьою лактацією внутрігрупова різниця надою була досить істотною та перевищувала міжгрупову.

Загалом, оцінка дочок окремих бугаїв білоголової ук- раїнської породи за ознаками молочної продуктивності дозволила виявити кращих плідників, до яких слід віднести Орла UA 235 і Сома UA6800085660 з високою продуктивністю дочірніх потомків за третю лактацію.

Сила впливу бугая на надій корів-первісток, визначена за допомогою однофакторного дисперсійного аналізу, була не істотна і становила $3,4 \%$. Тобто, за існуючих середовищних чинників в даному стаді роль бугая нівелюється.

Розведення худоби білоголової української породи методами чистопородного розведення за постійної проблеми інбридингу, зменшення чисельності поголів'я активної частини популяції та невисока продуктивність тварин змусили застосувати ввідне схрещування з гронінгенською породою.

Проведений нами порівняльний аналіз молочної продуктивності чистопородних та помісних тварин першої генерації засвідчив ефективність використання даного методу. За даними досліджень, чистопородні корови за першу лактацію продукували на 339 кг молока менше, ніж помісі першої генерації за практично однакового вмісту жиру в молоці (табл. 3). Кількість молочного жиру, як і величина надою була вищою у помісних тварин. Помісні корови виявилися продуктивнішими за чистопородних й за другою лактацією, оскільки продукували на 262 кг молока і 6,4 кг молочного жиру більше без статистично достовірної різниці між групами.

Таблиця 3

Молочна продуктивність корів за чистопородного розведення та ввідного схрещування $(\mathrm{n}=8)$

\begin{tabular}{|c|c|c|}
\hline \multirow{2}{*}{ Показник } & \multicolumn{2}{|c|}{ Порода та породність } \\
\hline & БУ & $50 \%$ БУ + 50\% ГР \\
\hline \multicolumn{3}{|c|}{ I лактація } \\
\hline Надій за 305 днів, кг & $3922 \pm 224,32$ & $4261 \pm 220,61$ \\
\hline Жир, \% & $3,55 \pm 0,02$ & $3,53 \pm 0,02$ \\
\hline Молочний жир, кг & $139,2 \pm 8,13$ & $150,6 \pm 7,99$ \\
\hline \multicolumn{3}{|c|}{ II лактація } \\
\hline Надій за 305 днів, кг & $4230 \pm 264,25$ & $4492 \pm 176,92$ \\
\hline Жир, \% & $3,66 \pm 0,04$ & $3,59 \pm 0,02$ \\
\hline Молочний жир, кг & $155,1 \pm 10,84$ & $161,5 \pm 6,73$ \\
\hline
\end{tabular}

Примітка. БУ - білоголова українська порода; ГР - гронінгенська порода; 50\% БУ + 50\% ГР - генотип помісних тварин першого покоління

Встановлений прямий середньої величини кореляційний зв'язок між віком та живою масою при першому осіменінні, який у чистопородних корів становив $r=+0,696$, а у помісних $-r=+0,463$. Водночас у чистопородних корів білоголової української породи, а також помісей першого покоління вік першого осіменіння мав зворотні та низької сили коефіцієнти кореляції з величиною надою за першу лактацію $(r=-0,01$ та $r=-0,237)$.

Практикою зарубіжного та вітчизняного скотарства визнано, що схрещування порід є методом значного підвищення основних ознак продуктивності. З'ясовано, що такий метод дає можливість отримати більше продукції кращої якості при менших витратах кормів і часу.

3 урахуванням чого для одержання ефекту гетерозису за молочною продуктивністю неактивну частину худоби білоголової української породи схрещували з джерсейською породою. Згідно одержаних нами результатів, помісні телиці характеризувалися більш пізнім (на 0,8 місяців) віком першого осіменіння, але більшою на 20,4 кг живою масою порівняно з чистопородними ровесницями (табл. 4). Ймовірно, за однакового віку осіменіння телиць їх жива маса не відрізнялася б між собою. Чистопородні корови білоголової української породи за першу лактацію продукували на 917 кг молока менше, ніж помісі першої генерації. Молоко помісних тварин містило на 0,12\% більше жиру, ніж у чистопородних корів. Вищий вміст жиру та більша кількість молока за лактацію сприяли одержанню у помісних корів більше молочного жиру, ніж у чистопородних особин без статистично достовірної різниці.

Наші дослідження щодо ефрективності схрещування худоби різних порід для підвищення основних селекційних ознак у помісних тварин першої генерації узгоджуються 3 висновками багатьох інших дослідників $[11,28,29]$ і дають підставу рекомендувати просте промислове схрещування худоби білоголової української з джерсейською породою для підвищення молочної продуктивності корів в умовах виробництва молока на промисловій основі. 
Відтворювальна здатність та молочна продуктивність корів за чистопородного розведення та промислового схрещування $(\mathrm{n}=5)$

\begin{tabular}{|l|c|c|}
\hline \multicolumn{1}{|c|}{ Показник } & \multicolumn{2}{|c|}{ Порода та породність } \\
\cline { 2 - 3 } & 4/п & \multicolumn{2}{|c}{$50 \%$ БУ + 50\% Д } \\
\hline Жива маса при першому осіменінні, кг & $305,4 \pm 18,25$ & $16,3 \pm 0,77$ \\
\hline Вік першого осіменіння, днів & $15,5 \pm 0,51$ & 46,65 \\
\hline Надій за 305 днів першої лактації, кг & $3744,6 \pm 204,76$ & $3,85 \pm 0,01$ \\
\hline Жир, \% & $3,73 \pm 0,003$ & $178,4 \pm 24,17$ \\
\hline Молочний жир, кг & $143,7 \pm 13,09$ & \\
\hline
\end{tabular}

Висновки 3 проведеного дослідження і перспективи подальших розвідок у цьому напрямку.

1.Вплив року народження корів чинить суттєвий вплив на їх молочну продуктивність, тому може бути одним із середовищних факторів поліпшення господарськи корисних ознак худоби білоголової української породи.

2.Кращою молочною продуктивністю за три лактації характеризувалися дочки бугаїв Орла UA235 і Сома UA6800085660, але загалом сила впливу бугая на величину надою корів-первісток була неістотною і становила 3,4\%.

3.Помісні корови першого покоління за ввідного схрещування білоголової української породи з гронінгенською характеризувалися вищою молочною продуктивністю, порівняно із чистопородними тваринами білоголової української породи, що дає гарні передумови для підвищення генетичного потенціалу та зниження гомозиготності тварин локальної популяції.

4.Схрещування корів білоголової української породи з бугаями породи джерсей забезпечує прояв гетерозису, який проявляється у вищій молочній продуктивності помісних тварин й може бути використаний в умовах промислового виробництва молока.

\section{Список використаної літератури:}

1. Бащенко М. І.. Гладій М. В Мельник Ю. Ф. Єфіменко М. Я. та ін. Стан і перспективи розвитку молочного скотарства України / Розведення і генетика тварин. 2017. Вип. 54. С. 6-14. DOI: https://doi.org/10.31073/abg.54.01.

2. Вінничук Д. Т., Пабат В. О. Обгрунтування системи селекції в товарних стадах голштинізованої молочної худоби : методичні рекомендації. Київ : Нива, 1996. 28 с.

3. Вечорка В. В., Салогуб А. М., Бондарчук В. М., Хмельничий С. Л. Реалізація генетичного потенціалу молочної продуктивності бугаїв-плідників. Вісник Сумського національного аграрного університету. Серія: Тваринництво. Суми, 2018. Вип. 2 (34). С. 30-33.

4. Войтенко С. Л., Вишневський Л. В. Білоголова українська порода в історичному аспекті. Вісник Сумського національного аграрного університету. 2016. Вип. 7 (30). С. 51-57.

5. Войтенко С. Л., Вишневський Л. В. Сучасний стан та перспективи розвитку білоголової української породи. Розведення і генетика тварин. 2016. Вип. 52. C. 194-202. DOI: https://doi.org/10.31073/abg.52.26.

6. Войтенко С. Л., Сидоренко О. В. Ефективність розведення худоби білоголової української породи. Науковотехнічний бюлетень IT HАAH. 2020. № 124. C. 232-245. DOI: 10.32900/2312-8402-2020-124-232-245.

7. Гавриленко М. С. Результати використання корів голштинської породи. Розведення і генетика тварин. 1999. Вип. 30. С. $47-53$.

8.Зубец М.В., Буркат В.П., Мельник Ю.Ф. и др. Генетика, селекция и биотехнология в скотоводстве - К. : «БМТ», 1997. $-722 \mathrm{c}$.

9. Іляшенко Г. Д. Формування господарськи корисних ознак корів залежно від походження за батьком. Розведення і генетика тварин. 2017. Вип. 54. С. 50-58. DOI: https://doi.org/10.31073/abg.54.06.

10. Єфіменко М., Подоба Б., Братушка Р. Перспективи розвитку української чорно-рябої молочної породи. Тваринництво України. 2014. № 5. С. 10-14.

11. Косилов В. И., Мироненко С.И. Повышение мясных качеств бестужевского скота путем скрещивания с симментальскими. Зоотехния. 2009. № 11. С. 2-3.

12. Кругляк А. П. Методичні основи використання кросбридингу в молочному скотарстві. Розведення і генетика тварин. 2016. Вип. 52. С. 41-48. DOI: https://doi.org/10.31073/abg.52.07.

13. Кузнецов А. Влияние быков на долголетие и продуктивность дочерей. Молочное и мясное скотоводство. 2009. № 5. C. 12-13.

14. Кураш В. Г., Булка В. М., Кругляк А. П., Подоба Б. Є. та ін. Білоголова українська порода - резерв спадкового матеріалу, адаптованого до умов України. Розведення і генетика тварин. 1999. Вип. 31- 32. С. 132-133.

15. Лабинов В. В., Прохоренко П. Н. Черно-пестрая порода молочного скота: состояние и направления совершенствования с использованием генофонда голштинской породы. Молочная промьшиленность. 2015. № 2. С. 56-59.

16. Лакин, Г.Ф. Биометрия : учебное пособие [для биол. спец. вузов] М. : Высшая школа, 1990. 352 c.

17. Олешко В.П. Ефективність використання бугаїв-плідників у племінних стадах молочної худоби. Розведення і генетика тварин. 2010. № 44. С. 135-139.

18. Омелькович С. П. Молочна продуктивність та відтворна здатність корів української чорно-рябої молочної породи різних генотипів. Збірник наукових праць Вінницького національного аграрного університету. 2014. Вип. 1 (83), т. 2. С. 159165.

19. Піддубна Л. М. Голштинізація відкритої регіональної популяції чорно-рябої молочної худоби та перспективи її 
подальшого удосконалення. Біологія тварин. 2014. № 4, т. 16. С. 121-132.

20. Пелехатий М. С., Піддубна Л. М. Оцінка бугаїв за комплексом ознак дочок-первісток у стаді молочної худоби. збірник наукових праць Подільського державного аграрно-технічного університету: серія «Технологія виробництва $і$ переробки продукції тваринництва». 2013. Вип. 21. С. 205-208.

21. Пославська Ю.В., Федорович Є.І., Бабік Н.П. Вплив сезону народження та сезону отелення корів на їх молочну продуктивність. Науковий вісник Львівського національного університету ветеринарної медицини та біотехнологій імені С.3. Гжицького. Львів, 2015. Т. 17, № 3 (63). С. 297-302.

22. Прохоренко П. Н., Логинов Ж. Г. Голштино-фризская порода скота. Ленинград : Агропромиздат, 1985. 238 с.

23. Рубан С., Федота О. Система підбору пар у сучасному молочному скотарстві. Agroexpert. 2017. № 10. C. 41-48.

24. Самусенко, Л. Д. Молочная продуктивность голштинизированных черно-пестрых коров в зависимости от генотипа и линейной принадлежности. Весник ОрелГау. Орел, 2010. № 6 (27). С. 101-103.

25. Сидоренко О. В., Войтенко С. Л., Полупан Ю. П., Джус П. П. та ін. Сучасний стан і рекомендації з ведення племінної роботи з автохтонними породами тварин в Україні. Полтава: ПП Астрая, 2020. 45 с.

26. Филь С. І., Федорович Є. І., Боднар П. В. Молочна продуктивність корів-дочок різних бугаїв-плідників. Науковий вісник Львівського національного університету ветеринарної медицини та біотехнологій імені С.3. Ґжицького. Серія: Сільськогосподарські науки. Львів, 2019. Т. 21. № 90. С. 68-75. DOI: 10.32718/nvlvet-a9012.

27. Шарафутдинов Г., Шайдуллин Р., Тюлькин С. Использование голштинских производителей разной селекции. Молочное и мясное скотоводство. 2007. № 6. С. 21-23.

28. Шемігон О. І. Результати схрещування лебединської породи із швіцькою. Розведення і генетика тварин. 1995. Вип. 27. С. 42-46.

29. Шендаков А. И. Устойчивость признаков у симментал-голштинских коров. Зоотехния. 2006. № 7. С. 4-5.

30. Щербатий 3. Є., Боднар П. В. Молочна продуктивність корів української чорно-рябої молочної породи дочок різних голштинських бугаїв. Науковий вісник Львівського національного університету ветеринарної медицини та біотехнології ім. С.3. Ґжицького. 2015. Т. 17. № 3 (63). С. 347-354.

31. Allore H. G., Oltenacu P. A., Erb H. N. Effekts of Season, Heard Size and Geographic Region on the Composition and Quality of Milk in the Notheast. Journal of Dairy Saience. 1997. № 11. P. - 3040-3049.

32. Cassell B. G., Jobst S. M., McGilliard M. L., Pearson R. E. Evaluating Sire Selection Practices Using Lifetime Net Income Functions. Journal of Dairy Saience. 2002. № 12. P. 3492-3502.

\section{References:}

1. Bashchenko, M. I. Hladii, M. V Melnyk, Yu. F. Yefimenko, M. Ya., A. P. Kruhliak ta in., Polupan Yu. P., Vyshnevskyi L. V., Biriukova O. D., Kruhliak O. V., Kuzebnyi S. V. and Pryima S. V., 2017. Stan i perspektyvy rozvytku molochnoho skotarstva Ukrainy [State and perspectives divelopmen of dairy cattle of the Ukraine] Rozvedennia i henetyka tvaryn, issue. 54, pp. 6-14. DOI: https://doi.org/10.31073/abg.54.01.

2. Vinnychuk, D. T., Pabat, V. O., 1996. Obgruntuvannia systemy selektsii $v$ tovarnykh stadakh holshtynizovanoi molochnoi khudoby: metodychni rekomendatsii [Substantiation of the selection system in commercial herds of Holsteinized dairy cattle: guidelines]. Kyiv: Nyva.

3. Vechorka, V. V., Salohub, A. M., Bondarchuk, V. M. and Khmelnychyi, S. L., 2018. Realizatsiia henetychnoho potentsialu molochnoi produktyvnosti buhaiv-plidnykiv [Realization of genetic potential of dairy productivity of sires]. Visnyk Sumskoho natsionalnoho ahrarnoho universytetu. Seriia: Tvarynnytstvo, issue 2 (34), pp. 30-33.

4. Voitenko, S. L. and Vyshnevskyi, L. V., 2016. Biloholova ukrainska poroda v istorychnomu aspekti [Ukrainian Whitehead Breed in historical perspective]. Visnyk Sumskoho natsionalnoho ahrarnoho universytetu, issue 7 (30), pp. 51-57.

5. Voitenko, S. L. and Vyshnevskyi, L. V., 2016. Suchasnyi stan ta perspektyvy rozvytku biloholovoi ukrainskoi porody [Modern condition and prospects of development of the Ukrainian Whitehead breed]. Rozvedennia i henetyka tvaryn, issue 52, pp. 194-202. DOI: https://doi.org/10.31073/abg.52.26

6. Voitenko, S. L. and Sydorenko, O. V., 2020. Efektyvnist rozvedennia khudoby biloholovoi ukrainskoi porody [selection efficiency of inbred cattle of Ukrainian Whitehead breed]. Naukovo-tekhnichnyi biuleten IT NAAN, no 124, pp. 232-245. DOI: https://doi.org/10.32900/2312-8402-2020-124-232-245.

7. Havrylenko, M. S., 1999. Rezultaty vykorystannia koriv holshtynskoi porody [The results of the use of Holstein cows]. Rozvedennia i henetyka tvaryn, issue 30, pp. 47-53.

8. Zubetc M.V., Melnik lu.F., Efimenko M.la., Petrenko I.P., Khavruk A.F., Krugliak A.P., Kuznetcov V.E., Antonenko V.I., Bashchenko M.I., Bliznichenko V.B., Guzev I.V., Kostiuk A.G., Podoba B.E., Chirkova O.P., Volenko I.S, Ladyka V.I. and lanko T. S., 1997. Henetyka, selektsyia y byotekhnolohyia v skotovodstve [Genetics, breeding and biotechnology in cattle breeding]. K.: «BMT».

9. lliashenko, H. D., 2017. Formuvannia hospodarsky korysnykh oznak koriv zalezhno vid pokhodzhennia za batkom [Relationship of milk productivity of cows with live weight and age at the first insemination]. Rozvedennia i henetyka tvaryn, issue 54, pp. 50-58. DOI: https://doi.org/10.31073/abg.54.06.

10. Yefimenko, M., Podoba, B. and Bratushka, R., 2014. Perspektyvy rozvytku ukrainskoi chorno-riaboi molochnoi porody [Prospects for the development of the Ukrainian Black-and-White Dairy breed]. Tvarynnytstvo Ukrainy, no 5, pp. 10-14.

11. Kosilov, V. I. and Mironenko, S. I., 2009. Povyshenie miasnykh kachestv bestuzhevskogo skota putem skreshchivaniia s simmentalskimi [Improving the meat qualities of the Bestuzhev cattle by crossing with Simmental]. Zootekhnii, no 11, pp. 2-3.

12. Kruhliak, A. P., 2016. Metodychni osnovy vykorystannia krosbrydynhu v molochnomu skotarstvi [Methodical basis of 
crossbreeding using in dairy cattle]. Rozvedennia i henetyka tvaryn, issue 52, pp. 41-48. DOI: https://doi.org/10.31073/abg.52.07.

13. Kuznetcov, A., 2009.Vliianie bykov na dolgoletie i produktivnost docherei [Influence of bulls on longevity and productivity of daughters]. Molochnoe i miasnoe skotovodstvo, no 5, pp. 12-13.

14. Kurash, V. H., Bulka, V. M., Kruhliak, A. P., Podoba, B. Ye. and Stoianov, R. O., 1999. Biloholova ukrainska poroda rezerv spadkovoho materialu, adaptovanoho do umov Ukrainy [The Whiteheaded Ukrainian breed is a reserve of hereditary material adapted to the conditions of Ukraine]. Rozvedennia i henetyka tvaryn, issue. 31- 32, pp. 132-133.

15. Labinov, V. V. and Prokhorenko, P. N., 2015. Cherno-pestraia poroda molochnogo skota: sostoianie i napravleniia sovershenstvovaniia s ispolzovaniem genofonda golshtinskoi porody [Black-and-White Dairy breed of cattle: state and directions of improvement using the gene pool of the Holstein breed]. Molochnaia promyshlennost, no 2, pp. 56-59.

16. Lakin, G. F., 1990. Biometriia : uchebnoe posobie dlia biol. spetc. vuzov [Biometrics: a tutorial for biol. university specialists]. M.: Vysshaia shkola.

17. Oleshko, V. P., 2010. Efektyvnist vykorystannia buhaiv-plidnykiv u pleminnykh stadakh molochnoi khudoby [Efficiency of use of breeding bulls in breeding herds of dairy cattle]. Rozvedennia i henetyka tvaryn, no 44, pp. 135-139.

18. Omelkovych, S. P., 2014. Molochna produktyvnist ta vidtvorna zdatnist koriv ukrainskoi chorno-riaboi molochnoi porody riznykh henotypiv [Dairy productivity and reproductive capacity of Ukrainian Black-and-White Dairy cows of different genotypes]. Zbirnyk naukovykh prats Vinnytskoho natsionalnoho ahrarnoho universytetu, issue 1 (83), vol. 2, pp. 159-165.

19. Piddubna, L. M., 2014. Holshtynizatsiia vidkrytoi rehionalnoi populiatsii chorno-riaboi molochnoi khudoby ta perspektyvy yii podalshoho udoskonalennia [Holsteinization of open regional population of Black-and-White cattle and prospects of its further improvement]. Biolohiia tvaryn, no 4, vol. 16, pp. 121-132.

20. Pelekhatyi, M. S. and Piddubna, L. M., 2013. Otsinka buhaiv za kompleksom oznak dochok-pervistok u stadi molochnoi khudoby [Assessment of bulls by a set of traits of first-born daughters in a herd of dairy cattle]. Zbirnyk naukovykh prats Podilskoho derzhavnoho ahrarno-tekhnichnoho universytetu: seriia «Tekhnolohiia vyrobnytstva i pererobky produktsii tvarynnytstva», issue 21, pp. 205-208.

21. Poslavska Yu.V., Fedorovych Ye.I. and Babik, N. P., 2015. Vplyv sezonu narodzhennia ta sezonu otelennia koriv na yikh molochnu produktyvnist [Influence of birth season and calving season of cows on their milk productivity]. Naukovyi visnyk Lvivskoho natsionalnoho universytetu veterynarnoi medytsyny ta biotekhnolohii imeni S.Z. Gzhytskoho, vol. 17, no 3 (63), pp. 297302.

22. Prokhorenko, P. N. and Loginov, Zh. G., 1985. Golshtino-frizskaia poroda skota [Holstein-Friesian cattle]. Leningrad: Agropromizdat.

23. Ruban, S. and Fedota, O., 2017. Systema pidboru par u suchasnomu molochnomu skotarstvi [The system of selection of pairs in modern dairy farming]. Agroexpert, no 10, pp. 41-48.

24. Samusenko, L. D., 2010. Molochnaia produktivnost golshtinizirovannykh cherno-pestrykh korov $v$ zavisimosti ot genotipa i lineinoi prinalezhnosti [Milk productivity of Holsteinized Black-and-White cows depending on genotype and lineage]. Vesnik OrelGau, no 6 (27), pp. 101-103.

25. Sydorenko, O. V., Voitenko, S. L., Polupan, Yu. P., Dzhus, P. P Dudka, O. I. Fursa, N. M., Pryima, S. V. and Ilnytska, T. Ye. 2020. Suchasnyi stan i rekomendatsii z vedennia pleminnoi roboty z avtokhtonnymy porodamy tvaryn $v$ Ukraini [Current state and recommendations for breeding with indigenous breeds of animals in Ukraine]. Poltava: PP Astraia.

26. Fyl, S. I., Fedorovych, Ye. I. and Bodnar, P. V., 2019. Molochna produktyvnist koriv-dochok riznykh buhaiv-plidnykiv [Milk productivity of cows-daughters from different bulls]. Naukovyi visnyk Lvivskoho natsionalnoho universytetu veterynarnoi medytsyny ta biotekhnolohii imeni S.Z. Gzhytskoho. Seriia: Silskohospodarski nauky, vol. 21, no 90, pp. 68-75. DOI: https://doi.org/10.32718/nvlvet-a9012.

27. Sharafutdinov, G., Shaidullin and R., Tiulkin, S., 2007. Ispolzovanie golshtinskikh proizvoditelei raznoi selektcii [The use of Holstein producers of various breeding]. Molochnoe i miasnoe skotovodstvo, no 6, pp. 21-23.

28. Shemihon, O. I., 1995. Rezultaty skhreshchuvannia lebedynskoi porody iz shvitskoiu [The results of crossing the Lebedyn breed with the Swiss]. Rozvedennia i henetyka tvaryn, issue. 27, pp. 42-46.

29. Shendakov, A. I., 2006. Ustoichivost priznakov u simmental-golshtinskikh korov [Trait persistence in Simmental Holstein cows]. Zootekhniia, no 7, pp. 4-5.

30. Shcherbatyi, Z. Ye. and Bodnar, P. V., 2015. Molochna produktyvnist koriv ukrainskoi chorno-riaboi molochnoi porody dochok riznykh holshtynskykh buhaiv [Ukrainian Black Spotted cows' Dairy breed daughters' milk productivity of different holstein bulls]. Naukovyi visnyk Lvivskoho natsionalnoho universytetu veterynarnoi medytsyny ta biotekhnolohii im. S.Z. Gzhytskoho, vol. 17, no 3 (63), pp. 347-354.

31. Allore, H. G., Oltenacu, P. A. and Erb, H. N., 1997. Effekts of Season, Heard Size and Geographic Region on the Composition and Quality of Milk in the Notheast. Journal of Dairy Saience, no 11, pp. 3040-3049. DOI: https://doi.org/10.3168/jds.S0022-0302(97)76271-4.

32. Cassell, B. G., Jobst, S. M., McGilliard, M. L. and Pearson, R. E., 2002. Evaluating Sire Selection Practices Using Lifetime Net Income Functions. Journal of Dairy Saience, vol. 85, no. 12, pp. 3492-3502. DOI: https://doi.org/10.3168/jds.S00220302(02)74438-X. 
Voitenko Svitlana Leonidivna, Doctor of Agricultural Sciences, Professor

Sydorenko Olena Vasylivna, Ph.D. of Agricultural Sciences, Senior Research Fellow

Institute of Animal Breeding and Genetics nd. a. M.V. Zubets of NAAS (Chubynske, Ukraine)

Ukrainian White-Headed breed for purebreed breeding and crossing

Methods of purebred breeding with a breed of farm animals allow to preserve breed features, to fix desirable traits of ancestors in offspring, to consolidate selection groups, to improve productivity, but at a certain stage of work with it there is a problem of inbreeding and productivity reduction which are very difficult to solve. The Ukrainian White-Headed breed of cattle currently belongs to domestic local populations, in which inbred animals are present and which, given the low economically important characteristics, cannot compete not only with the world, but also with the best domestic breeds. With this in mind, the search for ways to increase the economically useful characteristics of animals and reduce the homozygosity of the population is one of the current problems. The research was conducted on livestock of Ukrainian White-Headed breed in LLC "Podilsky Gospodar" of Khmelnytsky region. The influence of bull, father of offspring and year of birth on the improvement of economically useful traits of cows in purebred breeding, as well as the possibility of using introductory crossbreeding to reduce the level of inbreeding in the herd and increase the genetic potential of cattle on the main selection traits. To determine the effectiveness of attracting white-headed Ukrainian cows to milk production on an industrial basis, we studied the effectiveness of their crossing with the Jersey breed. The main selection traits were determined based on the materials of the dairy cattle management system (DCMS "Intesel-Orsek") as of January 1,2018. It was found that the difference between the highest and lowest milk yield of Ukrainian White-Headed cows for the first lactation in 20092014 years of birth was $584 \mathrm{~kg}(P \leq 0.01)$, while the strength of the year of birth on the hopes of the firstborn was 9.4\% 0.001), fat content $-18.0 \%(p \leq 0.001)$, the amount of milk fat $-9.4 \%$. The highest milk productivity in 3 lactations was found to be the daughters of Orel's UA235 and Som's UA6800085660, but in general the influence of the bull's on cow productivity is insignificant, as the intragroup difference between milk yields between high-yielding and low-yielding daughter offspring exceeds one lactation for each of the three lactations. The strength of the bull's influence on the hopes of the firstborn was $3.4 \%$. It is proved that the use of introductory and industrial crossbreeding increases milk productivity in crossbreed cows, compared to purebred and can be used as methods to increase the genetic potential of livestock in milk production on a breeding and industrial basis.

Key words: cattle, bulls, year of birth, introductory and industrial crossing, purebred and local animals, productivity.

Дата надходження до редакції: 28.01.2021 р. 